\title{
Political Communication, Social Media, and Public Sphere: An Analysis to a Phenomenon in Bandung towards Smart City
}

\author{
Iis Jamilah, Kamal Faishal Akbar, Muhammad Abqori Gunawan, and Stanijuanita Marantika
}

\begin{abstract}
The Web 2.0 Era has influenced the dynamics of politics and democracy, both global and local level nowadays. At the local level, the rise of technology, communication, and information affects the political communication between the government and the citizen. One of the interesting phenomena about this is happening in Bandung city. Ridwan Kamil, the current Mayor of Bandung City, has brought the social media effect since the regional election 2013 until now. As the mayor city, he uses social media not only to create more public-friendly communication with the citizen but also to create more effective and efficient procedure of public service. The using of social media such as Facebook, Twitter, Instagram, and YouTube has managed to make huge mobilization of Bandung Citizen to be involved in government's activities and programs. There are two cases that this paper analyzes as the effect of the web 2.0 Era on political life in Bandung. First, the regional election in 2013, it was a huge success of creative campaign by using social media instead of using traditional one as political communication to promote Ridwan Kamil and to attract citizen to choose him. Second, the use of social media and websites to inform, report, and promote government's programs and activities to engage citizen to involve as a volunteer or participant in government's programs. Furthermore, this phenomenon has led the government of Bandung to develop Bandung to be a 'smart' city. This paper gives critical analysis about how media social as a public sphere in web 2.0 era impact on political communication between government and citizen in Bandung.
\end{abstract}

Index Terms-Democracy, political communication, public sphere, social media.

\section{INTRODUCTION}

Bandung is the capital city of West Java Province, Indonesia, which has the largest population in Indonesia. In 2014, according to the data from Statistic Center (in Bahasa, Badan Pusat Statistik) the population in Bandung was $2,483,977$ people [1]. That means the population of Bandung could reach 2.5 million people in 2015. Bandung has become interesting topic in Indonesia lately. The main reason of this is because the political and infrastructure changes that happen in Bandung rapidly. It is Ridwan Kamil, current mayor City of Bandung, who successfully generated and initiated some breakthrough program since elected in 2013 regional election. In the last one year from 2014 until 2015

Manuscript received January 9, 2016; revised March 14, 2016. This paper is supported by Universitas Padjadjaran.

I. Jamilah, K. F. Akbar, M. A. Gunawan, and S. Marantika are with the Faculty of Social and Political Science, Universitas Padjadjaran, Indonesia (e-mail: izzahjamilah@gmail.com,_kamalfaishal@gmail.com, qoriabqori@gmail.com,stanijuanita@gmail.com). there were 147 awards rewarded to Bandung City consisted of 61 Province Awards, 81 National Awards, and 5 International Awards.

Ridwan Kamil is a new figure in political life of Bandung City. Before elected as Mayor City for 2013 - 2018 period, he was a lecture at Bandung Institute of Technology (in Bahasa, Insitut Teknologi Bandung, ITB) and was a Youth Activist in Bandung. The involvement of Ridwan Kamil in direct regional election 2013 in Bandung until now is interesting issue to be analyzed. It is about how social media as a public sphere in Web 2.0 era has been affecting political communication and government public service in Bandung. There are two cases that this paper analyzes as the effect of social media in Bandung; the region election in 2013 and The Government Public Relation in Ridwan Kamil Era (2013 now).

The using of social media in regional election 2013, such as Facebook, Twitter, YouTube, and so on, was one of political communication that Ridwan Kamil did as a creative campaign to promote himself to the people of Bandung. At that time, he already had thousands followers in Twitter, and most of them were young people who adored him as he was a famous architect form Bandung for his work such as Tsunami Museum in Aceh Province (to commemorate Tsunami 2006) and Kota Baru Parahyangan Mosque (The best five building of the Year in 2010 according to ArchDaily.com). Besides, he was a youth creative and an environment activist in Bandung. This what made he was famous among the youngsters in Bandung City.

The creative campaign using socal media was a huge success campaign to make people chose Ridwan Kamil and his vice, Oded M. Danial. As mentioned before that Bandung has around 2.5 million populations and about $22.1 \%$ or around 579 thousand people are internet active user [2]. By using the development of internet and social media which is known as the Web 2.0 Era, the creative campaign of Ridwan Kamil was spread rapidly and tremendously vast to the people.

After elected as Mayor City of Bandung for 2013 - 2018 period, Ridwan Kamil continues to use social media as government public relation to promote his programs, to improve government public service, and to report progress of government activities to the citizen of Bandung City. From 2013, people can easily make a complaint and report to the government through the official account of Bandung Government or through the private account of Ridwan Kamil. This is a momentum that has brought radical change in political communication, public sphere, and democracy 
among people of Bandung City.

Furthermore, this phenomenon has led the government of Bandung City to build Bandung as a smart city. The government wants to build Bandung as the city "combining ICT and Web 2.0 technology with other organizational, design and planning efforts to dematerialize and speed up bureaucratic processes and help to identify new, innovative solutions to city management complexity, in order to improve sustainability and livability." [3] By using expand of internet and technology that is seen as a big potential to develop social, culture, and economic aspect in Bandung City.

\section{THEORETICAL FRAMEWORK}

The democracy, political communication, and media are always associated with liberal democracy. The term of liberal democracy emerged in 16 centuries in Europe with its famous slogan 'Liberty, Equality, and Fraternity'. In liberal democracy, information and transparency were the main condition this century, far after the emergence of liberal democracy theory, the scientists agreed that three main components of democracy regime are: constitution, political participation, and rational choice [4]. That's why to create these three main characteristics of democracy regime, all we need is to provide public transparency to the people. Knowledge and information are the basic need where people are free and have the same rights to participate and aggregate their political interest. This is what differentiate democracy regime from the dictator one.

Today in the Web 2.0 Era, the emergence of internet and social media have made information can be accessed easily by all people. The easily accessed information and the public transparency are two main conditions in building democratic life. The web 2.0 Era itself refers to "internet media that is not merely to connect an individual with computer set in era web 1.0, but further connect people to publish, to process, and to complete data as a platform or program that can be developed until the user with long network and plot" [5].

In connection with democracy, the Web 2.0 Era has affected the implementation of democracy whether at global, national, or local level in many aspects. One of the aspects that has been affected is the political communication. Political communication has a large scope and is a multidisciplinary topic. A lot of social scientists tried to define what political communication is, but there is not a single definition can represent the whole definition of political communication. One of definitions of political communication is from Lord Windlesham (1973) "Political communication is the deliberate passing a political message by sender to a receiver with the intention of making the receiver behave in a way that might not other wise done." [6] From that definition, we can assume that political communication has political purpose to affect the action of other people will take. Meanwhile, Meadow stressed on political consequences from political communication, that: "any exchange of symbols or message that to a significant extent have been shaped by, or have consequences for the functioning of political system."[7] This political consequence is the main thing that differentiates political communication with common communication.
Political communication has three main elements. They are media, political organizations, and citizen. [4] The media are important to transmit message from government to citizen or from citizen to government. Further, McNair said that there are five functions of the media to the democratic process. First, media are to inform citizen what is happening around them. Second, media are to educate the citizen. Third, media are to facilitate the formation of public opinion. Forth, media are for publicity of government and political institutions. And the last, media are for advocacy of political viewpoints. [4]

Political communication that is done by political actor cannot be separated with public sphere and public opinion. Public sphere according to Habernas is a realm of our social life. At first in the $18^{\text {th }}$ century in Britain, public sphere is a space something is public and 'open to all'. The function of public sphere was providing information to engage people in 'critical public debate'. [8] In modern function, the public sphere not only provides information but also is a place where public opinion is built. The public opinion itself refers to "critical reflection to public competent to form its own judgments" [8].

Public sphere has a function as a buffer zone between government and private sector to prevent government to act irrationally. In fact, the public sphere and public opinion are being affected by development of internet and media that make people easily get the information about policy or political phenomena that is happening in their lives. Nowadays, public sphere especially mass media and social media have gradually replaced political system where government can be monitored not only by the representative people or institution but also can be monitored through the critics and opinion from the citizen.[9]

As mentioned before, that one of public sphere today is social media. Social media is "medium in internet that enable users to present and express their selves or to interact, to work together, to share, to communicate with other users and building social bounding virtually"[5]. It can't be help that the emergence of social media has significant impact for the political life, democracy, public sphere, and public opinion. Further, Zizi Papacharissi said that with the Web 2.0 Era people are easier to take a part in political and public agenda, one of them is through the freedom of speech that is expressed by writing it in Blog, show it in YouTube, or by giving a comment in online pages [10]. The using of social media has emerged new reality call social-cyber reality. Actually, this reality is the extension of social reality theory by Budreau and Newman. This model then was developed by Gotved to be a social-cyber reality that includes structure, culture, and interaction. This connection will show us the transformation from real reality to the virtual reality [5].

By using the expansion of internet and social media as the public sphere, the political actors have their interest and messages communicated to the audiences. Political programs, policy statements, electoral campaign, pressure group campaigns, and critical campaign as a democracy process can be transmitted effectively through the social and mass media in the web 2.0 Era.

In other hand, the development of information, communication, and technology not only affects the political sector but also leads the city to improve itself to be 'smart 
city'. The concept of smart city is a very broad concept. The development of information, communication, and technology nowadays has led Bandung Government to build Bandung based on smart city concept. The definition of smart city itself is still debatable. One of definitions of smart city is " $A$ city that monitors and integrates conditions of all of its critical infrastructures, including roads, bridges, tunnels, rails, subways, airports, seaports, communications, water, power, even major buildings, can better optimize its resources, plan its preventive maintenance activities, and monitor security aspects while maximizing services to its citizens" [11].

There are eight factors to improve a city to be smart city: management and organization, technology, governance, policy context, people and communities, economy, built infrastructure, and natural environment [12]. These factors form the basis of an integrative framework that can be used to examine how local governments building smart city based on expanding information, communication, and technology.

\section{REGIONAL ELECTION 2013}

In regional election of Bandung City 2013, Ridwan Kamil - M. Oded Danial, one of candidates Mayor City used social media as creative campaign. Using social media as creative campaign had been done before in other places, for example Obama who used Facebook as the medium of his President Campaign in 2008. But in Indonesia, as a developing country where information, communication, and technology could not be accessed easily by all people, using social media as political campaign medium was not famous before. For example, in Bandung, using social media has just risen to fame recently in regional election 2013.

The rise of social media using such as Facebook, Twitter, Instagram, YouTube, Ask.FM and so on, has replaced the initial purpose of social media. At the beginning of emergence social media, the man purpose of it was as sharing space for private thing in life. But now, the social media has become a public sphere where people talk about issue, especially politics and share their ideas. Further, social media has become a machine to make a social movement. The same case that happening in Bandung. Bandung is the second city of the largest internet user after Jakarta, in Indonesia. Beside, in 2012, Bandung was the sixth city that produces tweets in Twitter after Jakarta, Tokyo, London, Sao Paolo, and New York [10].

It was Ridwan Kamil, one of eight Mayor City candidates, through his personal account @RidwanKamil did some political socialization and communication to the people of Bandung in regional election 2013. He personally sees social media as "a machine of social change and city management machine that has incredible power. That is why, I believe that social media is a future language. So, whoever can master the information will be the winner of the future." [2] That's why he used social media to do a campaign to promote himself and to attract Bandung citizen to be his volunteers in regional election 2013. By using of social media in Bandung regional election 2013, the method of campaign was no longer doing canvass, door to door, or face to face campaign but by simply using gadget then the information were spread vast and effectively.
Before elected as Mayor City of Bandung, Ridwan Kamil was famous enough in social media because he was an environment and youth activist. He was founder of some creative communities such as Indonesia berkebun (Indonesia Gardening Movement), BCCF (Bandung Creative City Forum), Bike $\mathrm{Bdg}$ (Bdg is abbreviation from Bandung), Imagine Bdg, Beberes Bdg, and so on. At that time, with the total 881,000 accounts of Twitter followers of his account, the candidate Ridwan Kamil - Oded M Danial successfully turned Twitter as the public sphere into a place where people as voters could interact with him easily without limited by time and space. The youngster was the target of social media campaign at that time. This way was effective enough because $60 \%$ Bandung citizen are people under 40 years old, well educated, and are internet active users.

The winning of Ridwan Kamil - Oded was something unpredictable because his opponent was incumbent of vice mayor city who had led Bandung for two periods. Besides, Ridwan Kamil is a new name in political world in Bandung city. According to Regional Election Commission (in Bahasa, Komisi Pemilihan Daerah, KPUD Bandung), Ridwan Kamil - Oded M Danial won by obtaining $43.24 \%$ votes or 434,130 votes from total 969,648 legal votes from total 1,658,808 voters in Bandung. It was a big gap that Ridwan Kamil-Oded got compared to the others candidate.

Here, we see Ridwan Kamil as political communicator had managed to make the receiver, in this case was the social media user, to choose him as the mayor city of Bandung in direct regional election 2013. The information that transmitted vast through the internet and social media made the creative campaign as the effective and efficient way to attract voters. From the table I below about the Bandung regional election 2013 result, we can see that Ridwan Kamil - Oded M Danial got the highest votes and left the other competitors, who did not use media social as a campaign medium, behind so far.

TABLE I: VOTES ON BANDUNG REGIONAL ELECTION 2013 Source: KPUD Bandung

\begin{tabular}{clc}
\hline \hline No & \multicolumn{1}{c}{ Candidates } & Votes \\
\hline 1 & Edi Siswandi - Erwan Setiawan & 169,526 \\
2 & Wahyudin Karnadinata - Tonny Apriliani & 79,728 \\
3 & Wawan Dewanta - Sayogo & 17,901 \\
4 & Ridwan Kamil - Oded M Danial & 434,130 \\
5 & Ayi Vivanda - Nani Rosada & 145,513 \\
6 & MQ Iswara - Asep Dedy Ruyadi & 73,617 \\
7 & Budi Setiawan - Rizal Firdaus & 26,064 \\
8 & Bambang Setiadi - Alex Tahsin & 13,168 \\
\hline \hline
\end{tabular}

\section{Social Media as a Medium of Political COMMUNICATION BETWEEN GOVERNMENT AND CITIZEN AFTER THE REGIONAL ELECTION 2013}

After elected as Mayor City of Bandung, Ridwan Kamil now has two great powers to control Bandung. The first one is social media and its network, and the second one is formal power as Mayor City. The first power, social media and its network, has purpose to create public transparency of government activities. With this transparency, Bandung citizen can easily control government from the website or 
official social media or citizen can easily make a complaint and report to government official account. It makes Bandung citizen take a part in political process of Bandung City Government. This is known as activist rationality theory, which is saying that the more people involve in political process, the better quality of the democracy. [13] (Ch. 4, pp. 62-72) Besides through the social networking, Ridwan Kamil makes a public-friendly communication with his citizen.

The social media movement by Ridwan Kamil doesn't stop at using Facebook and Twitter, he also uses Instagram account to keep in touch with Bandung Citizen. Until now, it has already 2.1 million accounts Instagram following @ RidwanKamil account. From all the social media accounts, Instagram has the most follower accounts. These accounts are used to share information, to collaborate social movement, to inform the government activities and also to promote government programs. Now, Bandung has its own program for each day in a week. There are six program in Bandung from Monday to Saturday, they are: Senin Gratis Damri (Free Bus For Students In Monday), Selasa Tanpa Rokok (Tuesday Without Smoking), Rebo Nyunda (Wednesday As Sunda Day), Kamis Inggris (Thursday As English Day), Jumat Bersepeda (Bike Day On Friday), and Sabtu Kuliner (Culinary Night In Saturday). Besides, there are some social movements in Bandung that were successfully initiated from his social media accounts, such as: BCCF (Bandung Creative City Forum), Indonesia Berkebun (Indonesia Gardening), Gerakan Sejuta Biopori (A million biopori movement), and Gerakan Pungut Sampah (Picking up the garbage movements).

These movements according to the social-cyber reality theory, it is a penetration of socio culture in real life to virtual life. Social media as a public sphere that affected by culture can make a social changing. This is how social media works as social changer machine:

\section{Problem issue vision $\rightarrow$ Idea Initiative $\rightarrow$ Community $\rightarrow$ Movement Resilient Culture}

The culture of that affects social movement in Bandung is Udunan culture (Sunda term of crowdfunding). 'Life is crowdfunding' this is the most famous motto among Sunda people. Sunda is native ethnic of West Java and Banten Province. There are approximately $15.41 \%$ ethnic Sunda from the total of Indonesia citizen. Bandung City as the capital city of West Java Province, most of the population comes from Sunda ethnic. Sunda ethnic is known for their kindness, politeness, friendliness, cheerfulness, and optimistic with their philosophy of life 'Silih asih, silih asah, silih asuh'. The philosophy means to love each other, to support each other, and to care each other. The purpose of orientation of the philosophy value is empowerment individual in social life to achieve the best quality of humanity so people can create better life. No wonder that the culture of 'Udunan' and 'Silih asih, silih asah, silih asuh' have very big effect on social movements in Bandung.

As the implication of the culture in social life of Bandung citizen, it's easy to create social movement and to attract people in nonprofit activities. Social media has exceeded its own function from merely a media to express ourselves to a media that builds inspiring social movement. There are two interesting moments to be discussed as the example of this social-cyber reality. The first one is Relawan KAA (Asian African Conference Volunteer) in 2015. Bandung was the host of commemoration $60^{\text {th }}$ Asian African Conference in 2015. As the result, Bandung Government needed a lot of help to hold the biggest event of 2015. As the response to this, government by using social media invited the youngster to participate as volunteer in this event. Amazingly, there were 7,000 volunteers that registered and participated at this event. Surely, it was a big help for Bandung Government, with 'Udunan' culture, it was easy for government to attract youngster to participate as volunteer in this Asian African Conference Commemoration.

The second example is after the Asian African Commemoration, so many public facilities in Bandung that broken. It was a big trending topic when a young man uploaded a photo while standing in a public bench and after that, the bench then found broken. It was @fadilahsimeray who took a photo and caused the bench broken. This bench was not the only one facility that broken, there were so many facilities that broken. Many people who saw the photo of @ fadilahsimeray with caption 'No rules for the young' in Instagram reported it to Ridwan Kamil. Ridwan Kamil then saw the photo and commented "Kamu memalukan! Do you know how much I fight day and night for those things to be there?" that means "Shame on you! Do you know how much I fight day and night for those things to be there?"

Realizing the photo was commented with angry comment by Mayor City of Bandung, then @ fadilahsimeray, bravely wrote an apologize letter through his Instagram account and tagged it to @ RidwanKamil. In the end of his letter, he said "To get your forgiveness, I will do everything include if I had to mop Braga street". This apologize letter then seen by Ridwan Kamil and still he decided to punish him.

As@ @adilahsimeray said that he was willing to mop Braga Street, then the punishment from Ridwan Kamil for him was mopping Bragra Street. Then Ridwan Kamil tweeted "siapa yang mau ikut \#ngepelbraga juga bareng @fadilahsimeray? bawa alat, air, sabun cuci sendiri. Bonus foto bareng pa wali" that means "who wants to come \#MopingBraga together @fadilahsimeray ? Please bring your own equipment, water, and soap. A photo session with Mayor City as the bonus." This invitation got big response from Bandung netizen. At the D Day of punishment, May $1^{\text {st }} 2015$, Fadilah the young man kept his promise and mop the braga street together with Ridwan Kamil and Bandung Citizen who volunteered to participate in mopping Bragra Street. But before mopping Braga Street, Ridwan Kamil punished him to do 60 push up. For Ridwan Kamil, he said that it's not important how clean or how long he mopped the Braga Street, but the most important thing is to make youngster to responsible for everything that they do. Besides, the invitation of mopping Braga street attracted many Bandung citizen to maintain udunan (crowdfunding, in this term is working together) culture.

From this case, Ridwan Kamil creates his image and build the good opinion about him among the citizen by using the social media as a public sphere. By forming self-image as a reformer Ridwan Kamil with his political communication 
managed to mobilize public support to be involved in programs that being generated.

\section{Government Public RELATION In Ridwan KAmil ERA}

According to the concept, Government Public Relation has function to inform policies and formal plans of government to the people in democracy regime [13] (Ch. 17, pp. 268-274) But, in the Web 2.0 Era this function is added with government transparency to public. As the President James Madison said "A popular government without popular information or the means of acquiring it is but prologue to a farce or tragedy perhaps both". Nowadays, government is challenged by the extreme openness situation in managing bureaucracy and democracy. This also happen in Bandung government where government must transparent in giving public service. By using the social media and internet, Bandung city tries to build people control over government by creating bureaucracy without boundaries. For example, the LAPOR system (Layanan Aspirasi dan Pengaduan Online Rakyat). Lapor is an online report that can be easily accessed by people to complaint or to report something to government. Furthermore, to improve public service government of Bandung city created e-kelurahan (e-district) service so people can easily create a document such as ID card by registering online.

By this Government Public Relation, there are some issues done as the response of the report from Bandung citizen. They are: the issue of beggar and street urchin, repairing of traffic lights and sign, moratorium billboard, Students acceptance in government school in Bandung, illegal parking, illegal merchant, construction permission, and availability of prayer room in Mall and public space. People also can easily address a complaint to the government through the official account of government divisions or through private account of Ridwan Kamil.

\section{BANDUNG TOWARDS SMART CITY}

The development of information, communication, and technology in web 2.0 era not only affect the political life but also lead Bandung to improve itself towards smart city. In infrastructure aspect, the government repairs and improves the infrastructure such as road, public facilities, and so on. The government of Bandung city builds so many public space to build Bandung as more livable city. The parks that have already built or revitalized such as Lansia Park, Photography park, Pasupati Park (Jomblo Park), Hero Park, Alun-Alun Bandung, Alun-Alun Ujung Berung, Vanda Park, and Cikapundung Park. The purpose of this development is to make Bandung as livable and friendly city.

Meanwhile, in bureaucracy sector, Government Bandung makes a bureaucracy reform. The purposes of this reformation are: to make bureaucracy without corruption, to make bureaucracy as an effective and efficient institution, to build bureaucracy transparency, to improve public service of bureaucracy, and to decentralized bureaucracy. Besides, with the Web 2.0 Era, bureaucracy in Bandung can easily be accessed via web and its own official account.
In addition, Bandung has two new programs to improve the public service called Bandung Command Center (BCC) and $\mathrm{X}$-igent Panic Button application. The programs have purpose to help government to create security and social order. Bandung Command Center and X-igent Panic Button application are basis data and media to facilitate Bandung citizen to do a report of an incident and then the report that government receive will be transmitted to the related unit in order to make further response and action.

Bandung Command Center (BCC) is an integrated data center and control room to all of Bandung City area. BCC is supported with CCTVs and loudspeakers that spread in some spotted area of Bandung city. This means that government can easily control the people and record the trespass in Bandung. With this facility, government through related unit can make decision and action quickly such as giving a warning through the loudspeaker or visiting the location. For example, if a car parked in forbidden area, and recorded in CCTV BCC. Government can give a warning through loudspeaker in that area in order to make the driver move his car. Up until now, there are 61 CCTVs in 20 spots from 4,000 target of CCTVs.

Another product from $\mathrm{BCC}$ is $\mathrm{X}$-igent Panic Button application or Panic Button. This application was launched in July $10^{\text {th }} 2015$ and can be easily downloaded in Play Store via Smart Phone. X-igent Panic Button application will record your data such as identity and user's closest family. This application will work when the user is on danger situation or in an incident and presses the button three times. The report will be automatically sent to BCC and the BCC alarm in control room will ring when there is a report from citizen. After that, the operator will call the user to verify whether it is true or not. After being verified, operator will send the report to related unit to give further action and response. Up until now, there are 1,221 reports from the citizen through $\mathrm{X}$-igent Panic Button application.

They are two main examples as the government efforts in developing Bandung towards smart city. The first one is development through improving infrastructure, and the second one is collaborating public service, government public relation, and public sphere with the development of information, communication, and technology. Actually, the program of Bandung Command Center and X-igent Panic Button is similarly with 911 program in America and 119 in South Korea. But, because this program is still new so it needs so many improvements in all aspect to make it perfect.

\section{CONCLUSION}

The Web 2.0 era affects human life in many aspects. It is not only affecting the development of information, communication, and technology aspect, but also affecting in political life. For example, the rapid change of social media and political life that happen in Bandung City. It is interesting to see how the function of social media changes from a media that merely as sharing media to express ourselves to be a public sphere where the large sum of information is transmitted and accessed easily. Social media has successfully changed the political communication way from the traditional one to the modern one such as creative 
campaign.

Ridwan Kamil, as the political communicator, he managed to create his image as a reformer among citizen through social media. As political communicator, he also succeeded to attract voters to choose him and mobilized citizen to be involved in programs that being generated by government. Further, the development information, communication, and technology in web 2.0 era affect the government performance in providing public service. The citizen of Bandung can easily monitor the government and interact each other through social media.

Social media in Web 2.0 Era Media has negative and positive effects. In one side, this era of wide openness of information can make the elected government vulnerable by addressing some issue in the public sphere. But in other side, if we can use it wisely, the social media can be machine build political consciousness among the citizen in the democratic process.

The development of information, communication, and technology should be maximized by the Government of Bandung City to build Bandung as Smart City. But, according to the concept of smart city, the government of Bandung City must make more effort to actualize Bandung as smart city. To make Bandung as smart city the government has to improve not only infrastructure sector but also economy, people and communities, governance, management, and organization city.

The use of social media as Government Public Relation in Bandung city is good example for another city and province in Indonesia. As the McNair said that there are three components in political communication; the media, organization, and the citizen. According to this, the other city in Indonesia can also create this condition if:

1) The media and information can easily be accessed

2) The political institution provides public transparency

3) The citizens are well educated and are internet active user.

The government public relation between government and citizen through social media is good for Indonesian democracy for monitoring government, creating transparency, and raising the public participation. It also means to create control public over government.

\section{REFERENCES}

[1] Jawa Barat in Figures 2014, BPS - Statistic Jawa Barat, 2014.

[2] R. Kamil, \#TETOT Aku, Kamu, dan Media Sosial, Bandung: Sygma Creative Media Corp, 2014.

[3] D. Toppeta. (2010). The smart city vision: How innovation and ICT can Build smart. Foundation. [Online]. Available: http://www.thinkinnovation.org/file/research/23/en/Toppeta_Report_ 005_2010.pdf.

[4] B. McNair, An Introduction to Political Communication, $5^{\text {th }}$ ed., New York: Routledge, 2011, ch 5, pp. 67-80.

[5] R. Nasrullah, Media Soial Prosedur, Tren, dan Etika, Bandung: PT Remaja Rosdakarya, 2015, pp. 15-47

[6] L. Wiendlesham, "Minister in ulster: The machinery of direct rule," Public Administration, vol. 51, no. 3, 1973.

[7] Alfian, Komunikasi Politik dan Sistem Politik Indonesia, Jakarta: PT Gramedia Pustaka Utama, 1993.
[8] J. Habernas, The Structural Transformation of Public Sphere, Cambridge, MA: MIT Paperback Edition, 1991, ch. 6, pp. 181-225.

[9] C. Fuchs. (2014). Social Media and the Public Sphere. University of Westminster. [Online]. Available: http://www.triple-c.at/index.php/tripleC/article/viewFile/552/529

[10] Z. Papacharissi, "The virtual sphere 2.0 the internet, the public sphere, and beyond," Handbook of Internet Politics, New York: Routledge, 2009 , pp. $230 ; 245$.

[11] R. E. Hall. The vision of a smart city. [Online]. Available: http://www.osti.gov/bridge/servlets/purl/773961-oyxp82/webviewabl e/773961.pdf

[12] H. Chourabi et al. Understanding smart cities: An integrative framework. [Online]. Available: http://ctg.albany.edu/publications/journals/hicss_2012_smartcities/hic ss_2012_smartcities.pdf

[13] H. Subiakto and R. Ida, Komunikasi Politik, Media, dan Demokrasi, $2^{\text {nd }}$ ed. Jakarta: Prenadamedia Group, 2012.

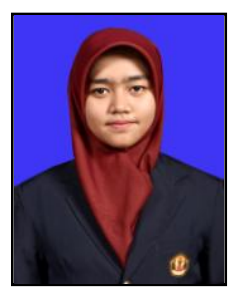

Iis Jamilah was born in Bandung, Indonesia in 1994. She is a student in the Universitas Padjadjaran, political science major since 2013. She is interested in democracy. The rapid political and democracy change that happen in Bandung has attracted her lately, that's why she wrote this paper with the tittle "Political communication, social media, and public sphere: An analysis to a phenomenon in bandung towards smart city"

Another paper of her work is "Bandung command center dan X-igent panic button sebagai upaya pemerintah kota bandung dalam mendukung komunitas politik-keamanan asean" or "Bandung command center and $\mathrm{x}$-igent panic button application as bandung government effort to support ASEAN political-security community" which won the third national paper competition in Universitas Gajah Mada this November 2015.

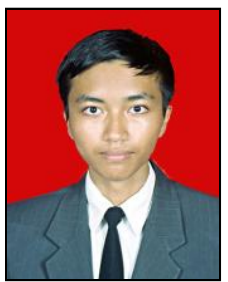

Kamal Faishal Akbar was born in Bandung, Indonesia in 1995. Kamal is a political science in Universitas Padjadjaran, political science major, since 2013. He is interested in political dynamic and democracy in Indonesia. He was also the author of 'Bandung command center and $\mathrm{x}$-igent panic button application as bandung government effort to support ASEAN political-security community' paper which won the third national paper competition in Universitas Gajah Mada this November 2015.



Muhammad Abqori Gunawan was born in Depok, Indonesia in 1996. He is a political science student in Universitas Padjadjaran, Political Science major, since 2013. He has interest in political communication and media social as a power to encourage social change in the society. He was also the author of "Bandung command center and $\mathrm{x}$-igent panic button application as bandung government effort to support ASEAN political-security community" paper which won the third national paper competition in Universitas Gajah Mada this November 2015

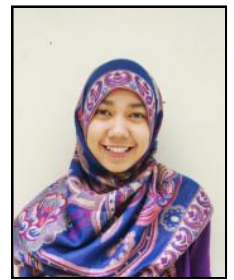

Stanijuanita Marantika was born in Cilacap, Indonesia in 1993. Stanijuanita is a student in Universitas Padjadjaran, international relations major, since 2011. She has interest in public diplomacy and Ridwan Kamil as role model as strategic leader, she admires due to turning Bandung in to a more livable city. She won national creativity paper competition by title "Development cooperation in tourism field between Asean-China" (2011) and was one of Indonesia delegations in International Youth Development Summit held by Philippine National Commission For UNESCO, Philippines (2014). 